\title{
Conhecimento em comunicação em dez respostas
}

\author{
Regina Helena Giannotti
}

GOMES, P. G.; FERREIRA, J.;

BRAGA, J. L.; FAUSTO NETO, A.(org.)

10 perguntas para a produção de conhecimento em Comunicação.

São Leopoldo: Unisinos, 181 p., 2013.

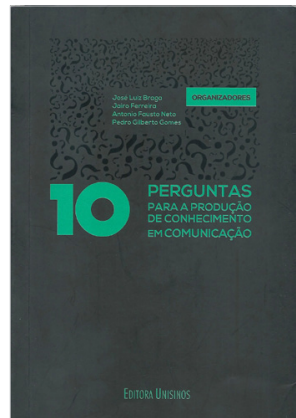

Resumo: $\mathrm{O}$ livro discute a necessidade das pesquisas em comunicação se debruçarem sobre os processos relacionais existentes entre os objetos empíricos e epistemológicos, observando os contornos que o objeto de comunicação vai adquirindo na medida em que as diferentes perspectivas de análise são utilizadas na "observação". Reúne reflexões de dez autores do grupo de trabalho sobre Epistemologia em Comunicação da Compós, instigando os demais pesquisadores a avaliarem tanto o conhecimento que é produzido quanto a escolha do método.

Palavras-chave: processos relacionais; objetos empíricos e epistemológicos em Comunicação; métodos de pesquisa; objeto de pesquisa.

Abstract: Knowledge in Communication in ten answers - This work discusses the need of research in communication look over existing relational processes between the empirical and epistemological objects observing the contours that an object of communication acquires as a relational processes while different perspectives of analysis are used in the observation. Gathers reflections from ten different authors of the Working Group on Communication in Epistemology urging other researchers to assess both knowledge that is produced as the choice of method.

Keywords: relational processes; empirical and epistemological objects in Communication; research methods; object of research. 
A coletânea Dez perguntas para a produção de conhecimento em comunicação é um dos resultados produzidos pelo grupo de trabalho Epistemologia da Comunicação cujos debates travados na Compós - Associação Nacional dos Programas de Pós-Graduação em Comunicação que vem, nos últimos quatro ou cinco anos, firmando-se como importante centro de discussões acerca desse campo.

Objetivando estudar a natureza da comunicação a partir do conhecimento nela produzido, os autores que participam de Dez perguntas partiram de um entendimento comum para elaborarem suas contribuições: o de que há uma inevitável indeterminação do objeto científico da comunicação, e há de considerar que variáveis sociais, econômicas, políticas e culturais o atingem.

Apesar de haver unanimidade sobre o fato de que a pergunta de pesquisa delimita o objeto, em Dez Perguntas, os autores demonstram que, na medida em que o contorno epistemológico é delineado, o objeto de comunicação ganha novas possibilidades de observação, pois é o exercício epistemológico que tem primazia sobre a "fixidez" da ciência. Afinal, o que é a experiência científica: o caminho percorrido ou as respostas encontradas?

Ao questionar-se sobre o que é especificamente comunicacional nos estudos brasileiros de comunicação da atualidade, Signates observa que a maioria dos estudos e pesquisas no campo da comunicação tem sido fundamentado em teorias de outras disciplinas científicas, que não levam em consideração o objeto específico da comunicação.

Para ilustrar suas observações, o autor toma como exemplo a ementa da linha de pesquisa Mídia e Cidadania do mestrado em Comunicação da UFG para demonstrar que tanto o objeto quanto o próprio campo da comunicação se situam em áreas de fronteira. Observa, por exemplo, as diferentes definições que a expressão «noções de cidadania» pode conter quando analisada pelas diferentes áreas do saber, mas ressalta que é nessa interface relacional que emerge o objeto da comunicação.

Ao abordar as relações entre as imagens irradiadas pelos processos midiáticos e o imaginário dos sujeitos, Medeiros nos convida a refletir tanto sobre a necessidade de resgatar a interação com o imaginário quanto de considerá-lo nos processos de pesquisa em comunicação, pois o imaginário depende não apenas das imagens visíveis, mas das imagens reconstruídas pelo receptor. No mundo do imaginário, os símbolos são fundamentais, mas, por si só, eles não propõem nada; apenas sugerem.

Quando discutiu a forma como as linguagens afetam e são afetadas pela circulação, Fausto Neto (2014) adverte sobre os novos contornos adquiridos pela linguagem e como a circulação passa a ser vista como um "lugar de embates". Ao revisar certos conceitos, o autor preocupa-se em observar as possíveis alterações que afetem a estrutura do discurso jornalístico, em especial, em sociedades em vias de midiatização, pois nessas a circulação, por exemplo, ao invés de agir como técnica converte-se em meio. Em outras palavras, todos passam a ser emissores alterando a lógica de produção e de recepção ou as condições de produção e de recepção. 
Ao examinar a convergência epistemológica na comunicação promovida pelo método pragmaticista, Pimenta questiona se tal método de pesquisa é útil para compreendermos o modo como se dão os processos comunicacionais. Essa concepção apresentada pelo autor se articula com o propósito da Máxima Pragmática de Pierce cujo percurso rumo ao conhecimento transcende as operações mentais da dedução e da indução.

Enquanto alguns pesquisadores examinam os métodos de pesquisa, Júnior indaga sobre a possibilidade de relacionar, em um mesmo objeto de estudos, a comunicação em geral e a comunicação mediada. Ou seja, ele pergunta como estabelecer interfaces entre a comunicação e outras áreas de conhecimento. Para isso, ele espera que quatro pontos fundamentais da comunicação (o entre, a audiência, a linguagem e o movimento) possam servir de base para pensar quais são os possíveis caminhos para dar continuidade às investigações. Apesar de a ênfase hoje recair sobre o meio, é importante que ela também recaia sobre a relação, pois as interfaces parecem hoje ser mais determinantes do que os meios.

Por outro lado, Silveira Jr toma como referência o estado da arte sobre Epistemologia e Pesquisa em Comunicação, condensado por Sodré (2012) no artigo intitulado «Comunicação: um campo em apuros teóricos». O autor investiga os tipos de vínculo, isto é, os laços comunicativos que devem ser detectados nas situações em exame, pois todas as tentativas de circunscrever a comunicação no âmbito das ciências sociais não têm sido bem-sucedidas, visto que em todas elas os autores extrapolam suas fronteiras. É o constante fluxo e a movimentação dos acontecimentos efetivos da sociedade que transbordam as fronteiras das ciências sociais e passam a exigir da comunicação tanto ferramentas de análises próprias quanto dinâmicas que acompanhem a movimentação desses acontecimentos, pois do contrário estarão fadados à obsolescência de partida.

Intrigado com o valor do conhecimento produzido no campo acadêmico pelos pesquisadores da comunicação, Gomes indaga como o processo de midiatização um novo modo de ser no mundo - afeta as relações sociais. Preocupado em desvelar os processos que subjazem aos meios, o autor pergunta qual é o método mais adequado para quem pretende pensar a midiatização e os processos midiáticos. Ocorre que, na maioria das vezes, preocupamo-nos mais com o método a utilizar do que com as possibilidades de abordagem que os métodos oferecem ao pesquisador. Isso é o que o autor chama de «a pergunta pela pergunta», ou seja, dependendo do que se pretende observar, um método pode se ajustar melhor ao processo de pesquisa do que outro. O resultado do conhecimento a produzir é mediado pelo método.

No campo das ciências sociais, a possibilidade de uso de múltiplos métodos rendeu e continua a render uma série de discussões sobre o conhecimento que nelas é produzido. Diversamente das ciências naturais, cujos métodos científicos são mais rígidos, as ciências sociais têm o homem, em sociedade e em grupo, como objeto que permite relativizar a própria definição de objeto. A diferença nos dias de hoje é que estamos em uma sociedade em estado de midiatização, que socializa com maior rapidez os conhecimentos 
acumulados pela humanidade, conforme ressalta Gomes. Ao escolher o método de investigação, estarão pressupostas as categorias de análise da pesquisa a ser desenvolvida.

Tanto Santos quanto os demais autores, que participam de Dez Perguntas, ressaltam em suas percepções acerca do fenômeno da comunicação que ela tanto pode ser reconhecida quanto se reconhecer como um campo de conhecimento que possui certa autonomia para dialogar com outros campos de conhecimento. Esperam eles também que Dez perguntas possa suscitar novas questões e possíveis respostas que façam a área de comunicação superar os desafios colocados à sua frente.

Regina Helena Giannotti é publicitária e professora do Departamento de Ciências Sociais Aplicadas do Centro Universitário FMU e doutoranda do Programa de Estudos Pós-Graduados em Comunicação e Semiótica da PUC-SP. rgiannotti@uol.com.br

\section{Referências}

SODRÉ, M. Comunicação: um campo em apuros teóricos. Revista MATRIZes, São Paulo, n. 2, p. 11-27, jan. [jun], 2012. 